and offered naval protection for the reconstruction of the base. The incident was quickly brushed off as a misunderstanding, but relations had been strained. Less than a decade later, the international Antarctic Treaty set aside the territorial disputes that fuelled such skirmishes, and effectively handed the continent over to science.

Such lessons from history are a useful reminder that Antarctica has not always been the research utopia that it is now, and that it took the resolution of real tensions and difficulties to render the incident at Hope Bay a curious historical footnote rather than a sign of things to come. There are also lessons here for the Arctic; specifically, how to manage the region as tensions rise over its oil and gas reserves that are driving greater exploration as the sea ice dwindles.

As we report on page 13, the drive to locate and exploit fossilfuel resources in the Arctic continues apace. At a meeting in the Norwegian city of Tromsø last week, executives from oil and gas firms queued up to boast of the riches the region could offer to their companies and shareholders.

Politicians can see the potential too. Ola Borten Moe, Norway's minister of petroleum and energy, last month awarded 26 new production licences for mature offshore oil areas in the Norwegian Sea and Barents Sea. New oil and gas development is under way off Norway, Greenland, Alaska and the northern coast of Russia. According to a much-quoted 2008 estimate from the US Geological Society, about $13 \%$ of the world's remaining technically recoverable oil, and up to $30 \%$ of its gas, is in the Arctic - most of it under the Arctic Ocean.

Yet, in the wake of the April 2010 Deepwater Horizon oil spill in the Gulf of Mexico, the environmental risks of such a dirty industry expanding into a pristine environment are obvious. Two environmentalists who envisaged the impact of a spill in the Arctic called it "A frozen hell" in a Nature article published on the first anniversary of the Deepwater Horizon disaster (J. Short and S. Murray Nature 472, 162-163; 2011).

Such an accident would be a global catastrophe. What can be done, on a worldwide scale, to prevent an Arctic spill from happening, and to ensure a rapid and coordinated response to mitigate the impact if it did? How can scientists contribute?

Common wisdom at this point tends to highlight the difficulties

of political collaboration and governance in the Arctic, given the overlapping territorial claims and the lack of an agreement similar to the Antarctic Treaty. It is true that the Arctic Council - which represents the nations and people of the Arctic Circle - has so far done little to answer critics who dismiss it as a toothless talking shop.

Formed in its present state only in 1996, the council did, however, produce its first legally binding agreement between nations last year, which sets out the responsibilities of its members to contribute to search-and-rescue activi-

"The highnorth is no longer a place of interest to only a select few." ties. And it has now set up a task force to explore whether a similar agreement could be reached on how to prevent, prepare for and respond to Arctic oil pollution.

That process could yet be controversial Greenland has suggested it should include a formal liability and compensation scheme and it is in its early stages. The group held only its second meeting in St Petersburg, Russia, in December, but it is scheduled to report back on the various options next year.

If the council is serious about the exercise - which it should be, given that its members will be on the front line of any Arctic spill then it could offer a timely and useful contribution. To achieve this potential, it should open up the process as widely as possible, and follow through on plans to involve in its discussions experts from scientific and environmental fields, as well as representatives from the offshore oil and gas industry. It should aim high, and look to create a binding agreement that is legally enforceable.

If that means the council going beyond its comfort zone, then it could seek wider international support for such a move. Several non-Arctic nations, including China and India, are already eyeing the region and its opportunities, and have asked for representation on the council.

Their requests have triggered debate and some resistance, but they surely have merit. Like the far south, the high north is no longer a place of interest to only a select few. Nations in the Arctic Circle will rightly insist on having the biggest say, but all interested countries should at least be offered a voice. And to avoid polluting the Arctic is a cause behind which everyone can surely unite.

\section{Damage limitation}

\section{Spider webs are designed to cope with stress and disruption, favouring repair over rebuilding.}

$\mathrm{W}$ ith a proposed referendum on Scottish independence likely to happen in 2014, some 700 years after the Scots army triumphed over English forces at the symbolic Battle of Bannockburn, one tale that seems certain to be told in the build-up is the story of Scotland's King Robert the Bruce and the spider. According to legend, Bruce was hiding in a cave in the wake of several defeats when he was inspired to fight again after watching a spider persevere, and eventually succeed, in its repeated attempts to spin a web.

As Bruce - who led the Scots to victory at Bannockburn - discovered, failure does not come easily to a spider. And although the amazing properties of spider silk have fascinated us for generations, the secrets of their webs have remained elusive.

In a paper on page 72 of this issue, Markus Buehler at the Massachusetts Institute of Technology in Cambridge and his colleagues report on perhaps the most impressive design feature of a spider's web: its structural and mechanical strength. In research that both modelled webs and investigated those spun in situ by local garden spiders, the authors found that the strands of silk adapt to the amount of stress they experience, and how that stress is loaded onto them.

Under a light stress, a gentle highland breeze perhaps, the silk softens and extends, so allowing the web to retain its structure. But when a larger and more disruptive force strikes - such as a hand groping for a light switch in a dark attic - the silk strands first extend, then the most stretched of those strands become suddenly rigid and so break. This sacrifice of a strand or two localizes the damage, and keeps the rest of the web intact. Once the disturbance has passed, the spider can scurry out to repair the web, rather than being forced to rebuild. As Bruce - who exploited heavily wooded areas to conceal his preparations for the decisive battle - discovered, it is easier to persevere, and to succeed, when nature is on your side.

These are heady times for arachnophiles. Last month, a stunning shawl and cape woven from spider silk went on display at London's Victoria and Albert Museum. The two garments, which took eight years to create, contain silk produced by more than one million female Madagascan golden orb-weaver spiders, amassed by a team of 80 people. They used long poles to collect the spiders from their webs each day, and harvested their silk before returning them to the wild. The garments are the first textiles to be made from spider silk since a set of bed hangings displayed at the 1900 Paris Exhibition. It is
DNATURE.COM To comment online, click on Editorials at: go.nature.com/xhunqu another achievement for the power of perseverance. Or perhaps, as those set to campaign in 2014 for Scotland to remain part of the United Kingdom might stress, it marks a triumph of, and a tribute to, sticking together.. 